\title{
THE SANABRIA LAKE. THE LARGEST NATURAL FRESHWATER LAKE IN SPAIN
}

\author{
J. C. Vega ${ }^{1}$, C. de Hoyos $^{2}$ and J.J. Aldasoro ${ }^{1}$ \\ 1. Calle Lago n 10, 49300 Puebla de Sanabria. Zamora. Spain. \\ 2. Department of Ecology, Faculty of Biology, University of Salamanca. 37008 Salamanca. Spain
}

Keywords: Lake, Monomixis, Glaciarism, Oligotrophy, Cyanophyceae.

\begin{abstract}
The Lake of Sanabria, at an altitude of $1000 \mathrm{~m}$. above sea level, and a surface area of $3,187,500 \mathrm{~m}^{2}$ is of glacial origin. According to its physical and chemical factors this lake is oligotrophic, monomictic temperate, with a winter circulation at $8^{\circ} \mathrm{C}$ and thermal stratification in the summer. Its transparency is high (5-9 m., Secchi disk). The main nutrients are present at low concentrations, with a vertical distribution that is nearly homogeneous during winter circulation and with an orthograde trend during thermal stratification.

Its nutrient levels are not very closely related to greater abundances of phytoplanktonic algae. Chlorophyll levels are generally low ( mean 2,2 $\mu \mathrm{gr} . \mathrm{l}^{-1}$ ). Chroococcal Cyanophyceae and Chlorococcal Chlorophyceae are the best represented groups in the phytoplankton, specially during chlorophyll peaks. Other groups, such as Diatoms, Chrisophyceae and Criptophyceae are scarce.

Macrophytes are represented along the poorest ground shores by Isoetes velata, Myriophyllum alterniflorum and other species, and in the richest ones by Equisetum fluviatile and Eleocharis palustris.

Zooplankton are represented by 12 main Rotifer and Crustacean species that follow a stable pattern of succession. Their composition is characteristic of an oligotrophic lake.
\end{abstract}

\section{INTRODUCTION}

Located in the NW of Spain $\left(42^{\circ} 07^{\prime} 30^{\prime \prime N}, 06^{\circ} 43^{\prime} 00^{\prime \prime} \mathrm{W}\right)$ between the provinces of Leon and Zamora at $1000 \mathrm{~m}$. above the sea level, the Sanabria lake lies in the Tera river valley which has its sources in the mountain range of the Sierra Segundera and the Sierra Cabrera.(fig.1)

It is a glaciar lake, situated in a valley locked by a frontal moraine; Despite the possibility of some overexcavation at its bottom, it can be classified as type 30 according to the Hutchinson's classification (1967). Its only tributary and emissary is the Tera river. In the drainage basin there are two more rivers that join the Tera just before the lake (table 1, fig. 1). All these rivers run over an acid rock substrate (gneiss and granodiorites) of low solubility, and are very poor in salts.

The population resident in the drainage basin is very small, living in two villages, and shows negative demographic and socio-economic trends. However, the population increases sharply in the summer because of the important recreational use of the lake.
In the past. little attention has been dedicated to the lake by the scientific community. The most interesting work has been that of TABOADA (1912) who compiled the first bathymetric maps. In that same year, HALFBASS collected plankton samples that were determined by BACHMAN (1913). This worker determined 12 species of phytoplankton, one of them new. Later, Margalef also visited the zone in 1952 and carried out an extensive work on the lake's flora and fauna (MARGALEF, 1955). Currently, different studies are under way, as yet unpublished.

The aim of the present work is to describe novel results obtained between 1986 and 1989. These data were obtained following a limnological control program on the Sanabria lake and are expected to offer a better view of the dynamics of the lake.

\section{POPULATION AND WATER USE}

The resident population in the drainage area is now about 200 people, living in two villages. Both of then discharge 
their untreated sewage into the area. This discharge is of little importance, except in summer, when it increases sharply owing to the vacational tourist influx. The agricultural use of the land has considerably decreased over the last two decades and artificial fertilizers are not used.

Hidroelectrical reservoirs control the water supply by the three rivers that flow into the lake. This helps to maintain the water flow in the dry summers.(fig. 1).

\section{GEOLOGY AND GEOMORPHOLOGY}

The Sanabria lake occupies a glacial depression in the Tera valley (fig. 1) and is dammed by a frontal moraine. The basin is situated between the mountains of the Sierra Segundera and the Sierra Cabrera, characterized by their acid rocks of metamorphic or plutonic origin. These formations are composed by orthose- rich gneisses and some granodiorites. The low water solubility of these rocks leads to a very low ionic content in all the waters that run through the area and also those contained in the Sanabria lake.

During the Würm glacial period, two main glaciar arms descended from the Sierra Segundera highplain along the Tera and the Segundera and Cardena valley ensemble. Both of them were joined, forming a large glaciar arm in the lower part of Tera valley where the Sanabria lake is now located. This glaciar pushed morainic matter to the end of its course, damming the valley. Thus, the water filled the basin after the melting of the ices some 8,000 years ago. The only present lake effluent is the Tera river, that later joins the Esla (A tributary of the Duero river).

In the heights of the Sierra Segundera and Cabrera there are more than 20 ponds of glaciar origin and numerous bog pools.

\section{CLIMATE AND VEGETATION}

Climate is of the wet mediterranean mountain type with an annual mean temperature of $10.3^{\circ} \mathrm{C}$ and a total cumulative yearly rainfall mean of $1,400 \mathrm{~mm}$. The coldest month is February when temperatures reach a daily mean of $2 \cdot 4^{\circ} \mathrm{C}$. The highest temperatures are recorded in July and August when they rise to a mean of $19.8^{\circ} \mathrm{C}$.

In the drainage area vegetation is abundant and is mainly constituted, as expected in this climate, by young Quercus pyrenaica woodland. In the highplains of this area it is constituted by shrubs, pastures and bogs.
A

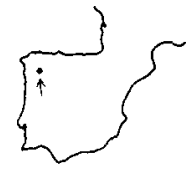

Sanabria Lake

$\because \because$ Reservoirs

$\sim$ Rivers
B

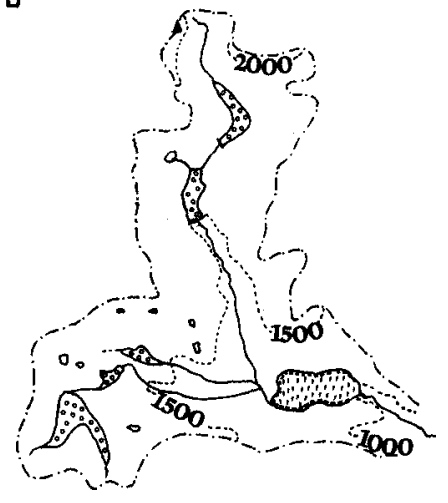

C

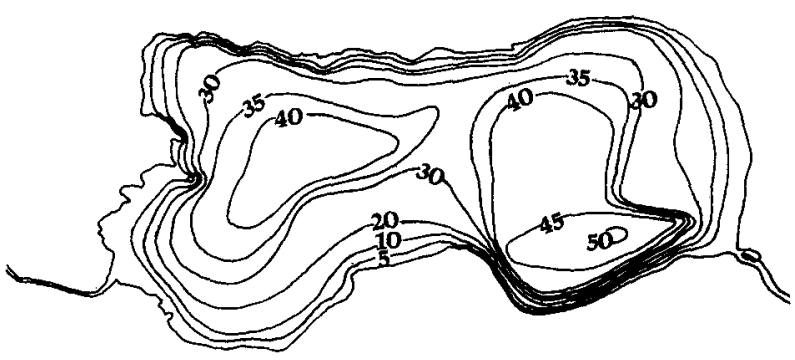

Figure 1. Geographical features and bathymery of the Sanabria lake. A: Location; B: Drainage area; C: Bathyrnetry.

\section{PHYSICAL FACTORS}

Temperature: The vertical distribution of the temperature of Sanabria Lake over several seasonal cycles (19861990) shows that it is a monomictic lake with winter circulation and summer stratification. The winter circulation corresponds to a homeothermy between 7 and 4-C, depending on the year (Figs. 2 and 3). The surface layers begin to warm at the start of the spring, reaching $20-24^{\circ} \mathrm{C}$ during the summer. A thermocline is detected from February to December in some years, but it usually begins to appear in March and in the first week of December it disappears. The depth of the epilimnion reaches about 10 meters during the summer. Hypolimnion temperatures range between 7 and $9^{\circ} \mathrm{C}$ in the same season.

The dynamics of oligotrophic monomictic lakes depend on the winter water circulation that ensures the renewal of nutrients in the photic layer.It also leads to oxygenation of the deep waters of the lake. Climatic conditions affect the strength and duration of the winter mixing, thus achieving a higher oxygen level in the waters in the colder winters (fig.2). 
Transparency: Transparency was measured by the Secchi disk metod and ranged from 9 to $5 \mathrm{~m}$. Minimal values were brought about by the rains generated turbidity in November and December and the maximal ones were recorded in the steady waters of the late summer and autumn (fig.3).

\section{CHEMICAL FACTORS}

Dissolved oxygen: The dissolved oxygen content underwent little variation in the epilimnion during the year; by contrast, in the hipolimnion it fell throughout the stratification period. The lowest hipolimnion concentrations were achieved at $50 \mathrm{~m}$. deep waters just before the overturn (November). Our data show that oxigen was not exhausted at any time in the Sanabria lake during the period studied (fig.2).

pH: pH exhibited small changes in the water column. Only slight and local increases in the epilimnion, due to photosynthesis were observed, and these values also declined slightly in the deepest layers during the low oxygen levels periods.(fig.4),

Ionic concentrations: The predominant cations were $\mathrm{Ca}^{2+}>\mathrm{Na}^{+}>\mathrm{Mg}^{2+}>\mathrm{K}^{+}$. Low amounts of $\mathrm{Fe}$ were also found (Table 2). The contribution of these ions was almost uniform during the year.

The levels of anions were low and also stable; some variations were only observed in bicarbonate. By decreasing order of abundance the anions were as follows: $\mathrm{HCO}_{3}{ }^{-}$ $>\mathrm{SO}_{4}{ }^{2}>\mathrm{Cl}^{-}$. The conductivity of the water was measured in several cycles and showed very low values, as corresponds to an acid soft water lake, increasing only during stratification in the deep hipolimnion (table 2).

Nitrate: Nitrate showed maximum concentrations near the bottom before the winter overturn due to the bacterial

\section{TEMPERATURE ${ }^{\circ} \mathrm{C}$}

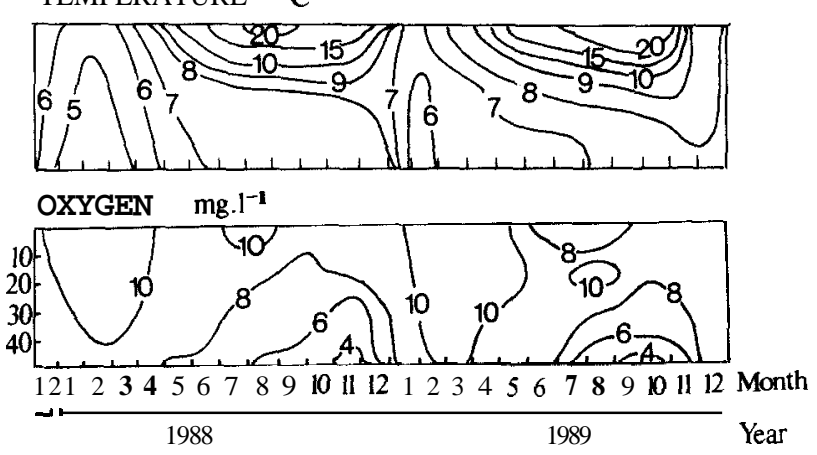

Figure 2. Depth-time distribution of temperatures and oxygen concentrations in the Sanabria lake.
Table 1. Morphometric and physical parameters of the Sanabria lake.

\begin{tabular}{|c|c|}
\hline Major axis & E-W \\
\hline Elevation (m) & 1.000 \\
\hline Maximum depth (m) & 51 \\
\hline Mean depth (m) & 35 \\
\hline Maximum length (m) & 3.178 \\
\hline Maximum width (m) & 1.590 \\
\hline Minimum width (m) & 906 \\
\hline Shoreline length $(\mathrm{m})$ & 9.350 \\
\hline Surface area $\left(\mathrm{m}^{2}\right)$ & 3.178 .500 \\
\hline Volume $\left(\mathrm{m}^{3}\right)$ & 108.254 .000 \\
\hline Mean annual inflow $\left(\mathrm{m}^{3}\right)$ & 287.000 .000 \\
\hline Water residence time (months) & 4,52 \\
\hline
\end{tabular}

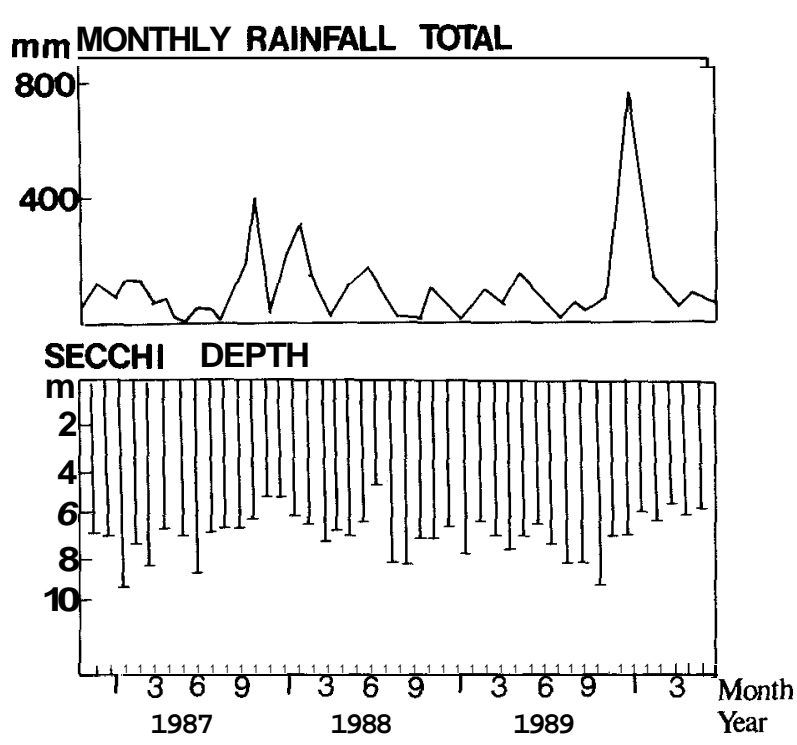

Figure 3. Total monthly rainfall. Secchi disk depth during the years studied in yhe Sanabria lake.

nitrification of the organic matter falling from the upper layers. Depletion, as a consequence of biological activity, occurred in the epilimnion during the autumn. Winter levels remained homogeneous throughout the column due to water mixing (fig.4). The concentration of this nutrient was high during winter owing to the redistribution produced by the mixing of waters and to externa1 sources; As was observed in all the annual cycles studied, this was mainly surface runoff via the Tera river (fig.5).

Phosphate: In general the phosphate concentration was very low (fig.4). However, a decrease was observed in the 
levels of this nutrient from the start of the measurement up to the present time.

Its vertical distribution ahowed a weak stratification in summer, with a slight increase near the bottom. Over the year, this nutrient gradually declined from winter to spring, reducing its concentrations and becoming almost depleted in the summer and autumn in the epilimnion (fig.5).

The most important source of phosphate is the run-off through the Tera river, mainly in the summer, when the population in the basin increases.

Silica: The concentrations of silica fluctuates within a small range of low values (1-1.8 $\left.\mathrm{mg}^{-1} \mathrm{l}^{-1}\right)$ with a certain stratification of these values during the summer (fig.4).
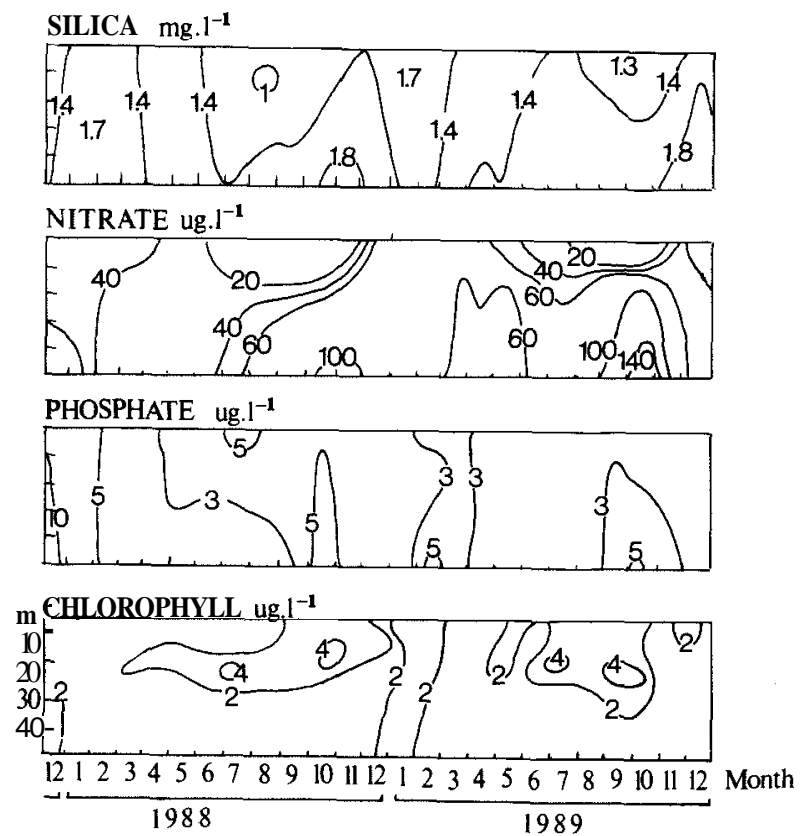

Figure 4. Depth-time distribution of silica, nitrate, phosphate, and chlorophyll concentrations in the Sanabria lake.

\section{BIOLOGICAL COMPONENTS}

Phytoplankton: The phytoplankton of the Sanabria lake is mainly composed by small Cyanophyceae and Chlorophyceae, indicating a strong predominance of nanoplankton (table 3, fig.6). Despite the small size of these cells, they contribute strongly to the total biomass. The dominance of Cyanophyceae was not continuous but was observed during certain sharp phases of growth. During these peaks large numbers of cells, close to 20,000 cells $/ \mathrm{ml}$ were observed (fig.6). In the annual cycles studied these maxima were recorded in May, December and July. No relationships between these maxima and nutrient availability or the physical and climatic features were observed.

The total number of cells and chlorophyll displayed a more regular pattern of growth. The major increases occurred in late summer to autumn. A low rate of growth was recorded during the spring (fig.5).

\section{NITRATE $\mu \mathrm{g} .^{-1}$}

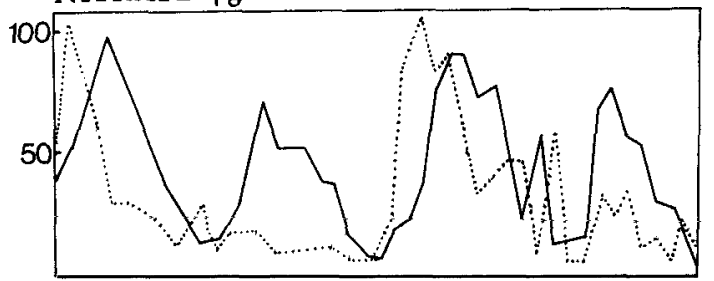

PHOSPHATE Hg. $\mathrm{l}^{-1}$

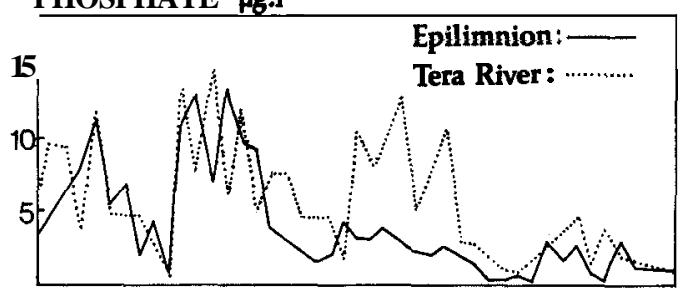

CHLOROPHYLL $\mu \mathrm{gg} . \mathrm{I}^{-1}$

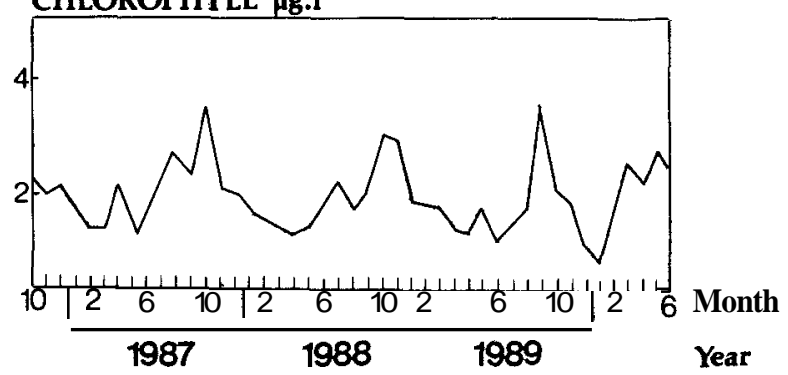

Figure 5. Evolution of epilimnetic mean concetrations $(0-15 \mathrm{~m})$ of nitrate, phosphate and chlorophyll during the years studied in the Sanabria lake.

The Chlorophyceae exhibited a noticeable diversity and contribution to biomass. This contribution increased, at least in mean values,over the last years of the study. A pattern of succession was also found with some species: in the winter overturn period, the genus Monoraphidium was present; this was substituted by Oocystis and Quadricoccus laevis in early spring. Thereafter, the summer waters contained Sphaerocystis, which was then succeeded by Crucigenia, at the end of autumn (fig.6). Desmidiaceae, a group characteristic of acid waters, even if not abundant, were represented by a 
Table 2. Chemical composition of the Sanabria lake.

\begin{tabular}{|c|c|c|}
\hline Parameter & Mean & Range \\
\hline Conductivity $\left(\mu \mathrm{S} / \mathrm{cm} / \mathrm{cm}^{2}\right)$ & 14.6 & $13-18$ \\
\hline Alkalinity (mEq. $\left.1^{-1}\right)$ & 0.03 & $0.01-0.07$ \\
\hline $\mathrm{pH}$ & 6.5 & $5.8-8.1$ \\
\hline Nitrite-Nitrogen $\left(\mathrm{mg}_{\mathrm{fl}} \mathrm{I}_{1}\right)$ & 0.00 & \\
\hline Ammonia-Nitrogen $\left(\mathrm{mg} . \mathrm{l}^{-1}\right)$ & 0.00 & \\
\hline Nitrate-Nitrogen $\left(\mu \mathrm{g} .1^{-1}\right)$ & 47.5 & $20-160$ \\
\hline Phosphate soluble phosphorus $\left(\mu \mathrm{g} \cdot \mathrm{l}^{-1}\right)$ & 2.7 & $0.5-22$ \\
\hline Total phosphorus $\left(\mu \mathrm{g} . \mathrm{I}^{-1}\right)$ & 11 & $4-18$ \\
\hline Iron $\left(\mathrm{mg} . \mathrm{l}^{-1}\right)$ & & $0.00-3$ \\
\hline Manganese (mg. $\left.\mathrm{l}^{-1}\right)$ & & $0.00-0.4$ \\
\hline Potassium (mg. $\left.\mathrm{l}^{-1}\right)$ & & $0.00-0.3$ \\
\hline Sodium $\left(\mathrm{mg}^{-\mathrm{l}^{-1}}\right)$ & & $0.4-1.8$ \\
\hline Calcium (mg. $\left.\mathrm{l}^{-1}\right)$ & & $0.5-1.6$ \\
\hline Magnesium (mg.l $\left.{ }^{1}\right)$ & & $0.13-0.7$ \\
\hline Sulphate (mg. $\left.\mathrm{l}^{-1}\right)$ & & $0.01-0.04$ \\
\hline Chloride (mg. $\left.\mathrm{l}^{-1}\right)$ & & 0.00 \\
\hline Bicarbonate (meq..$^{-1}$ ) & & 0.028 \\
\hline
\end{tabular}

large number of species. Diatoms were very poorly represented, as is usual in acid waters with a low silica contents. Only $100-200$ cells/ml were counted formy in the main growth seasons (spring or summer). Cryptophyceae were also very scarce but maintained a stable contribution during the cycles studied. Finally, Chrysophyceae and Dinoflagelates were found throughout the year, but not in very high numbers. Their strongest development occurred during the periods of stratification, in the water layer just above the thermocline.

Zooplankton: Figure 7 shows the density during a complete cycle of the main species forming the zooplankton: six species of Crustacea and another six species of Rotifera; other species were also observed (Table 3). During the year, these species followed a usual pattern of succession. Among the Crustacea, the following were dominant: Daph. nia longispina (Spring) and Diaptomus castaneti (Summer). Other crustacean species were also of interest, such as the thermophilic Diaphanosoma brachiurum which lives in upper water layers only in the summer and the species charachteristic of more eutrophic waters Bosmina longirrostris which, in some of the years studied, appeared during the summer or autumn (fig. 7,8 ).

The ratio between Cladocera and Calanoids, considered to be a good indicator of the trophic state of water was stable and low. The stability of the succession was striking although migrations were observed both vertical and horizontal. The highest density occurred at $5 \mathrm{~m}$. depth during the first hours of the afternoon in August (fig.8).

Rotifera fluctuated more, both in species number and composition, the two dominant species being Conochilus unicornis and Poliarthra remata. Table 3 shows other species of crustaceans and rotifers related with the macrophytes and the sediment.

\section{AQUATIC MACROPHYTES}

Fringing almost the whole of the water body, in the well illuminated zone, there is a narrow band of submerged vegetation dominated by two species: Isoetes velata and Myriophillum alterniflorum. In the more nutrient-rich sediment situated in the neighbourhood of the mouth of the Tera river, Equisetum fluviatile, Potamogetum natans and Eleochuris palustris are found.The Characeae alga Nitella flexilis inhabits shallows waters but in low biomass (table 3 ).

\section{DISCUSSION}

The Sanabria lake should be considered as oligotrophic in view of its low chlorophyll and nutrients concentration and producction rates (HUTCHINSON, 1967;MARGALEF, 
Table 3. List of the main species of phytoplankton, zooplankton fish and macrophytes identified in the Sanabria lake.

ALGAE

Cyanophyceae

Aphanotece sp

Coelosphaerium sp.

Microcystis sp.

Merismopedia glauca

Pseudoanahaena catenata

Chlorophyceae

Botryococcus braunii

Monoraphidium skujae

M. komarkovae

$M$. contortum

Quadrigula sp.

Elakatotrix gelatinosa

Ankistrodesmus fusiformis

Kirchneriela contorta

Oocystis submarina

O. lacustris

Quadricoccus laevis

Sphaerocystis sp.

Crucigenia quadrata

C. tetrapedia

Pediastrum tetras

Scenedesmus sp.

Staurastrum arktiskon

S. aculeatum

S. gracile

Staurodesmus jaculiferum

S. glabrum

S. laevispinum

Cosmarium contractum

Bacillariophyceae

Cyclotella glomerata

C. stelligera

Melosira distans

M. granulata

Tabellaria fenestrata

T. flocculosa

Gomphonema constrictum

Diatoma hiemale

Ceratoneis arcus

Crysophyceae

Ochromonas sp.

Bitrichia ochridana

Pseudopedinella gallica

Mallomonas $s p$.

M. akrokomos

Dinobryum sp

$D$. divergens

D. crenulatum

Cryptophyceae

Rhodomonas minuta

Criptomonas erosa

C. ovata

Dinophyceae

Peridinium inconspicuum

$P$. cinctum

Gymnodinium $s p$

Ceratium hirundinella

\section{CRUSTACEA}

Copepgda

Diaptomus castaneti ssp.castaneti

Tropocyclops prasinus

Cyclops strenuus

Macrocyclops albidus

Eucyclops serrulatus

Cladocera Daphnia longispina

Diaphanosoma brachyurum

Bosmina longirrostris

Ceriodaphnia quadrangula

Chidorus sphaericus

Alona quadrangularis

Alonella nana

Euricercus lamellatus

Acroperus harpae

Macrothryx hirsuticornis

ROTIFERA

Keratella cochlearis

K. quadrata

Trichocera similis

T. chatroni

Lecane perplesa

Polyarthra remata

$P$. vulgaris

Asplanchna priodonta

Conochilus unicornis

Collotheca pelagica

Ascomorfa ovalis

Filinia longiseta

Pleosoma hudsoni

Hexarthra intermedia

FISH

Salmo rrutta

Barbus hocagei

Cobitis calderoni

Leuciscus cephalus

\section{MACROPHYTES}

Potamogeton natans

Eleocharis palustris

Equisetum fluviatile

Isoetes velata

Nitella flexilis

Antinoria agrostidea

Baldellia ranunculoides

Callitriche stagnalis

C. hamulata

Ranunculus peltatus

Juncus fluitans

Myriophillum alterniflorum 

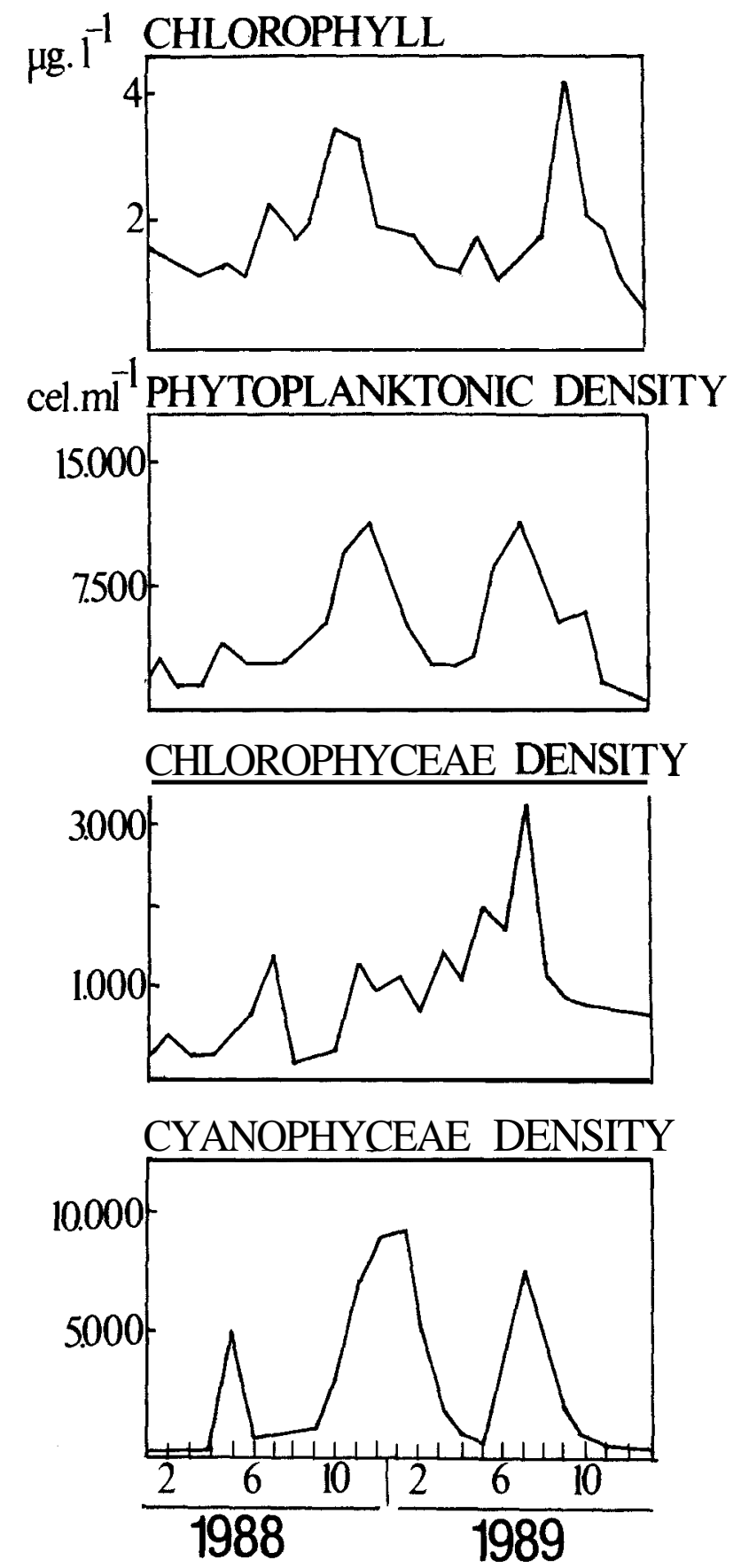

Figure 6. Evolution of epilimnetic chlorophyll, phyoplanktonic cell, Chlorophyceae and Cyanophyceae densities for the years 1988 and 1989 in the Sanabria lake.

1983). The lake's substrate, the low population of the basin and the recent decreases in agricultural activity would account for the low values in nitrate, phosphate and silica.
In recent years. a noteworthy decrease in phosphate levels (orthophosphate) was observed, accompanied by less pronounced decrease in nitrate levels. A rapid water renewal, rainfall, the contribution of the Tera river and biotic activity could account for such changes. In the case of phosphate, the main factor seems to be the supply from the Tera river. However, in the case of nitrates, the rises observed after mixing are not only due to the contribution from the Tera but also to the strong degree of water renewal produced by heavy rainfall (fig. 5 , table 4 ).

Seasonal variations in phytoplankton are generally considered to be closely related to the fluctuations in nutrients levels and with other factors such as temperature, turbulence, biological cycles, succession, predation and parasitism (MARGALEF, 1983). Phosphorus has been considered as the main limiting element in acid waters (VOLLENWEIDER, 1968; KALFF \& KNOECHEL, 1978). In the Sanabria lake it would be difficult to account for the evolution of phytoplankton in terms of only one of these factors.

In this lake, temperature did not limits certain periods of algal growth, specially those of the Chroococcal Cyanophiceae, as occurred in the winter of 1988-1989 (fig. 6). These algae can achieve a high growth rate in low temperature conditions (CRAIG, 1987). Chlorophiceae are also able to grow at low temperatures. However, the major rises in Chlorophyceae followed the natural seasonal cycles and a clear succession pattern during the year.

Other important groups, such as Diatoms and the Chrisophiceae are poorly represented, in contrast to other moun-
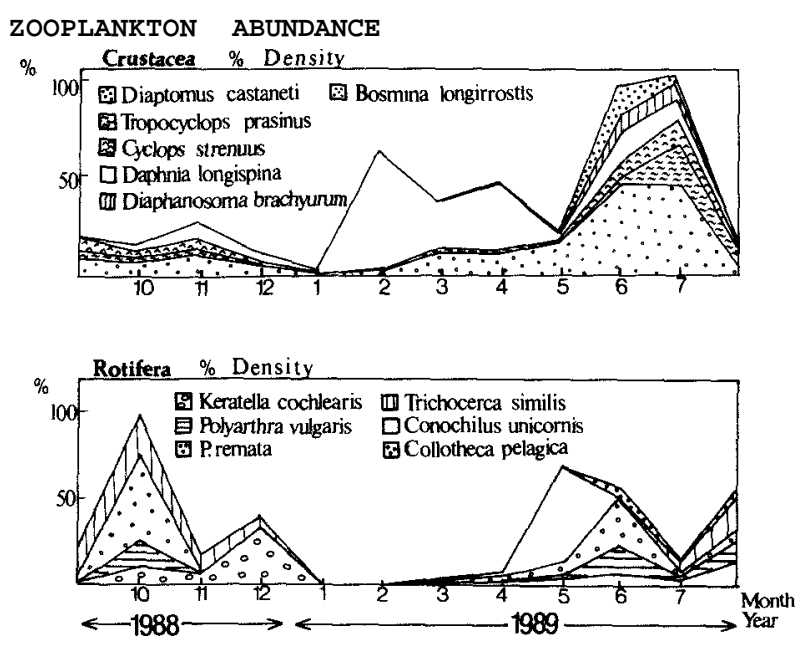

Figure 7. Evolution of zooplankton abundance during the years 1988 and 1989 in the Sanabria lake. 

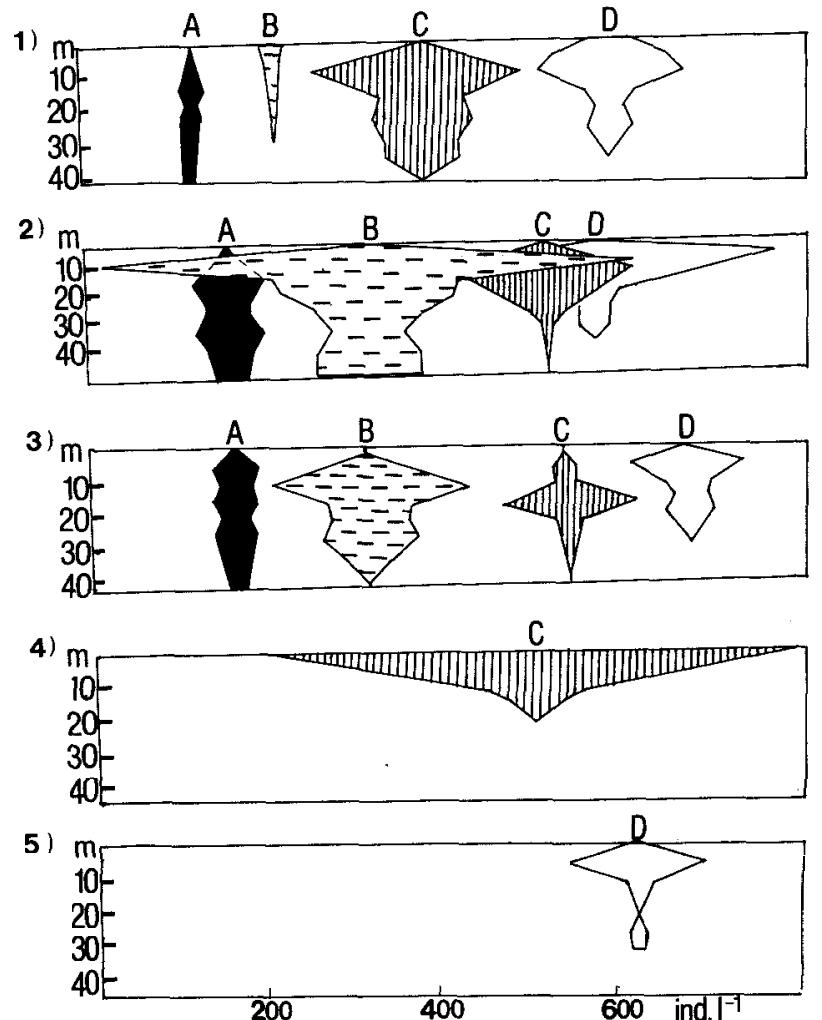

Figure 8. Zooplanktonic crustacean density along the water column (1986): 1, Tropocyclops prasinius; 2, Diapotomus castaneti; 3 , Daphnia longispina: 4, Diaphanosoma brachyurum: 5, Bosmina longirrostris. A. winter; B, spring; C, summer; D, aurumn. tain lakes such as those of the Pirineos mountains.In the case of the Diatoms, low level of silica together with the acid nature of the water could be responsible for this.

The chemical characteristics of the water might be determinants in the composition of the plankton, although they do not suffice to explain the changes in the communities of the dominant algae. The nitrogen levels of the upper water layers practically disappears as a result of the growth of algae (fig. 5). However, the most abundant algae of the lake (Cyanophyceae and Chlorophyceae) sometimes appear at times when the nitrate levels of the epilimnion are very low (September, 1988, summer, 1989) (fig. 6).

Phosphate levels underwent a noticeable decrease during the years studied. This trend was not observed, however, in the number of cells and the amount of chlorophyll (fig. 5). In the winter of 1988-89 a remarkable decrease in phosphates occurred, however, algae increased as usual in spring and to a greater extent in late surnmer. This growth was supported mainly by coccal Cyanophyceae and Chlorophiceae pointing to a low dependence on phosphate. (fig. 6)

Future observations and analysis should be undertaken to understand these processes more clearly. At some times during the cycles this lake displays a predominance of Cyanophyceae and low levels of nutrients, which shows that these algae are not always related to a process of eutrophization. SHUTTLE \& HARRISON (1988) have pointed to the abundant presence of Cyanophyceae in ultraoligotrophic lakes situated in the Rocky Mountains. The contribution of

Table 4. Means of nutrient concentrations and rainfall during the years studied.

\begin{tabular}{|c|c|c|c|c|c|}
\hline YEARS & 1986 & 1987 & 1988 & 1989 & 1990 \\
\hline \multicolumn{6}{|l|}{$\begin{array}{l}\text { Phosphate in } \\
\text { the Tera River }\end{array}$} \\
\hline$\left(\mu \mathrm{g} .1^{-1}\right)$ & 26.3 & 7.5 & 6.6 & 5.3 & 1.9 \\
\hline $\begin{array}{l}\text { Phosphate in } \\
\text { the lake }\left(\mu \mathrm{g} . \mathrm{I}^{-1}\right)\end{array}$ & 10.5 & 9.3 & 3.6 & 1.7 & 1.5 \\
\hline \multicolumn{6}{|l|}{$\begin{array}{l}\text { Nitrate in } \\
\text { the Tera River }\end{array}$} \\
\hline \multicolumn{6}{|l|}{$\begin{array}{l}\text { Nitrate in } \\
\text { the lake }\end{array}$} \\
\hline$\left(\mu \mathrm{g} .1^{-1}\right)$ & 62.5 & 56.5 & 40.2 & 58.6 & 42 \\
\hline Rainfall (mm) & 87.9 & 143.0 & 119.2 & 180.5 & 109.6 \\
\hline
\end{tabular}


the nanoplankton to the overall biomass of phytoplankton seems to be very important in oligotrophic lakes, despite the little attention that they have received (KALFF and KNOECHEL 1978). Their small size permits a better utilization of nutrients owing to the increase in the surface/volume ratio (KALFF \& KNOECHEL, 1978; PAVONI, 1963; KALFF et al., 1975). Evidence exists to suggest that the Cyanophiceae accumulate phosphorus during the phases prior to growth peaks (SUTTLE \& HARRISON, 1988). Other authors have speculated about their tendency to survive and thrive in waters with high contents in organic matter and the possibility that this might be used by the algae (CRAIG, 1987; FOGG, 1973). In the Sanabria lake, high levels of organic matter could be accumulated, specially with the arrival of the autumn rains, which would contribute large amounts of particulate and non-particulate organic matter.

The Cyanophyceae are usually considered to be good indicators of eutrophication; however this is not the case of the lake of Sanabria where their growth occurs at very low nutrient concentrations. In other cold oligotrophic and ultraoligotrophic lakes, their importance has also been underscored. In the light of such data, we consider it important to bear in mind the complexity characterizing these oligotrophic lakes and that a review should be made of certain limnological concepts valid for more mineralized lakes but difficult to implement for oligotrophic mountain lakes with softer waters.

The zooplankton follows normal trends, with stable seasonal cycles, showing growth in spring of Daphnia longispina followed by two more thermophile species, Diaptomus castaneti and Diaphanosoma brachyurum. Finally, an autumn specie appears: Bosmina longirrostris (fig.7, 8).

The Rotifers are dominated by two species: Conochilus unicornis, in spring, and Polyarthra remata in autumn. These show more unstable cycles than the crustaceans (fig. 7).

The taxonomic composition of the zooplankton is consistent with that reported by several authors for oligotrophic lakes (TONOLLI, 1962; MC NAUGHT, 1975; EDMONSON, 1977).

\section{ACKNOWLEDGEMENTS}

Work supported by the Consejería de Medio Ambiente de la Junta de Castilla y Leon. Dirección del Parque Natural del Lago de Sanabria.

The authors wish to thanks to José María García Zorrilla for his important contribution to the study of Zooplankton, and to the Director of the Parque Natural del Lago de Sanabria, D. Guido Rodríguez de Lema Blanco for his unconditional and continuous support in performing this study.

\section{REFERENCES}

BACHMAN,H. 1913: Plancktonproben aus Spanien, gesammet von Prof. Dr. Halbfas. Berichte des deustche Botanische Gesselbschaft 31: 183-188.

CRAIG, S.R. 1987: The distribution and contribution of picoplancton to deep photosynthetic layers in some meromictic lakes. Acta Academiae Aboensis 47: 55-87.

EDMONSON, W.T. 1977: Lake Washington and the predictability of limnological events. Univ. of Upsala. August 21-27.

FOG, G.E. 1969: The Physiology of an algal nuisance. Proc. R. Soc. London Ser. B. 173: 175-189.

HALBFAS, W. 1913: Der Catanedasee, der groste Süswasersee Spaniens und seine Ungebung. Peterman Mitteilungen 59: 306-312.

HUTCHINSSON, G.H. 1967: A Treatise on Limnology. Willey. New York.

KALFF,J.K. \& KNOECHEL, R. 1978: Phytoplankton and their dynamics in oligotrophic and eutrophic lakes. Ann. Rev.Ecol. Syst. 9: 475-495.

KALFF,J.K., KLING, H.J., HOLMGREN, S.H., \& WELCH, H.E. 1975: Phytoplankton growth and biomass cycles.

MARGALEF, R. 1955: Comunidades dulceacuicolas del NW de España.Pub. Inst. Biol: Apl. 21: 5-31.

MARGALEF, R. 1983:Limnologia. Omega. Barcelona. MAC NAUGHT, D.C. 1975: A hypothesis to explain the succession from Calanoids to Cladocerans during eutrophication. Verh.Internat. Verein. Limnol. 19: 724-731.

PAVONI, M. 1963: Die Bedentung des Nannoplanktons in Vergleich zum Netzplankton. Schweiz. Z. Hydrol. 25: 219-341.

SUTTLE, C.A. \& HARRISON, P.J. 1988: Ammonium and Phosphate uptake rates N:P supply ratios and evidence for $\mathrm{N}$ and $\mathrm{P}$ limitation in some oligotrophic lakes. Limnol. Oceanogr.33: 186-202.

TABOADA, J. 1913: El Lago de San Martin de Castañeda. Bol. Real Soc. Española Hist. Nat. 13: 960-986.

TONOLLI, V. 1961: Studio sulla dinamica dei popolamento di un copepode (Eudiaptomus vulgaris, Scheneil) Mem. Inst. Ital.Idrobiol. 13:179-202.

VOLLENWEIDER, R.A. 1968: Scientific fundamentals of eutrophication of lakes and flowing waters with particular references to nitrogen and phosphorus as factors in eutrophication.OCDE Directorate for scientific affairs. Paris. 


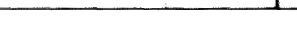

